\title{
Prinzmetal angina: echocardiographic captured and angiographically proven without provocative testing
}

\author{
Yashwant Agrawal (ㄷ, ${ }^{1}$ Pramod Kumar Ponna, ${ }^{2}$ Abdul R Halabi, ${ }^{1}$ Feras Aloka ${ }^{1}$
}

${ }^{1}$ Cardiology, Saint Joseph Mercy Oakland Hospital, Pontiac, Michigan, USA

${ }^{2}$ Internal Medicine, Saint Joseph Mercy Oakland Hospital, Pontiac, Michigan, USA

\section{Correspondence to Dr Yashwant Agrawal; yashwantagrawal.agrawal@ gmail.com}

YA and PKP are joint first authors.

Accepted 13 August 2020

\section{Check for updates}

(C) BMJ Publishing Group Limited 2020. No commercial re-use. See rights and permissions. Published by BMJ.

To cite: Agrawal Y, Ponna PK, Halabi AR, et al. BMJ Case Rep 2020;13:e236353. doi:10.1136/bcr-2020236353

\section{DESCRIPTION}

A 49-year-old man with a 25 pack-year history of tobacco abuse presented to our institution reported new onset severe left-sided chest pain. The patient experienced multiple episodes of chest pain which lasted for approximately $5 \mathrm{~min}$ each, radiating to left upper extremity. Symptoms occurred both at rest and on exertion for 2 days prior to admission. Physical examinations including vitals were unremarkable. ECG showed normal sinus rhythm without ischaemic changes. Serial cardiac biomarkers and urine drug screen resulted negative.

Transthoracic echocardiogram (TTE) revealed preserved left ventricle ejection fraction (LVEF) and normal wall motion when the patient was asymptomatic. During image acquisition, the patient developed recurrent chest pain associated with transient severe antero-apical wall hypokinesis with LVEF reduction to $35 \%-40 \%$ from $60 \%$ (video 1 ). Chest leads attached during TTE revealed new onset ST depression and T wave inversion. Chest pain resolved spontaneously along with the resolution of the above TTE and ECG changes. By the time of 12-lead ECG acquisition, the ECG changes had resolved. Repeat serial troponins resulted negative. He was started on heparin drip, aspirin, statin and scheduled for urgent $(\approx 4$ hours) cardiac catheterisation.

Coronary angiogram revealed severe (95\%) midsegmental left anterior descending artery stenosis

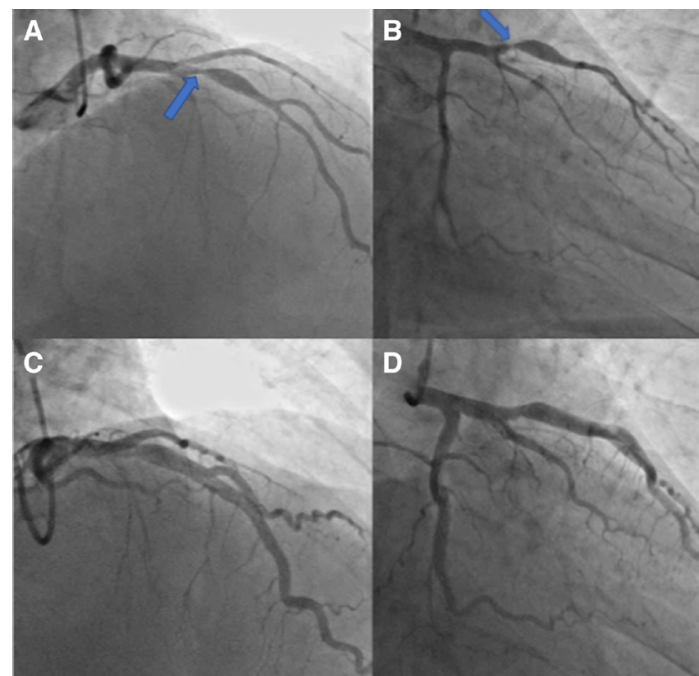

Figure 1 Coronary angiogram. (A and C) Right anterior oblique (RAO) cranial view. (B and D) RAO caudal view. Blue arrow revealing $95 \%$ stenosis of mid-left anterior descending artery ( $A$ and $B$ ) which significantly improved after intracoronary injection of nitroglycerin (C and D).

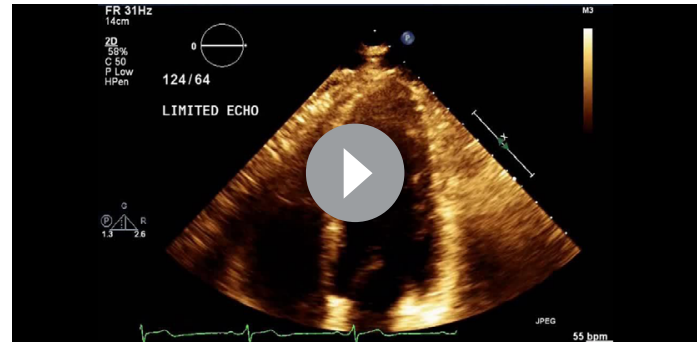

Video 1 TTE: 4 chamber view. Severe antero-apical wall hypokinesis

and a moderate $(50 \%-60 \%)$ long segment stenosis in posterior lateral branch of right coronary artery (figure 1A-B). Intracoronary nitroglycerin $(200 \mu \mathrm{g})$ was given due to high index of suspicion for coronary spasm. This resulted in remarkable improvement in stenosis of both the vessels and an increase in the calibre of all coronary arteries (figure 1C-D). The diagnosis of plurifocal coronary vasospasm was confirmed. The patient experienced intermittent, recurrent episodes of chest pain without any ECG changes during cardiac catheterisation. Subsequent left ventriculogram showed normal LVEF and wall motion. The patient was started on calcium channel blockers (CCBs). He has been asymptomatic in the outpatient follow-up visit and tolerating his medications. Thus, we decided not to perform provocative test on CCBs.

Prinzmetal angina is nitrate responsive chest pain which is intermittent total or subtotal focal coronary artery spasm causing greater than $90 \%$ reduction in the diameter. ${ }^{12}$ Pain is similar to typical angina in quality but tends to be more severe and prolonged. ${ }^{3}$ Smoking and recreational drugs like cocaine and amphetamine can contribute to coronary vasospasm. ${ }^{1}$

Gold standard for diagnosis is provocative coronary angiography. ${ }^{2}$ Ergonovine echocardiography can be safely used as diagnostic screening test for coronary vasospasm instead of invasive spasm provocation testing if significant fixed coronary stenosis is ruled out prior to the test. ${ }^{45}$ Coronary vasospasm is an important cause of myocardial ischaemia. Delayed diagnosis can result in acute infarctions, malignant arrhythmias and sudden cardiac death. ${ }^{12}$ Medical management includes CCBs and long acting nitrates. Emphasis should be also laid on smoking cessation.

Above case represents prinzmetal angina, 'caught in the act'. It has been rarely observed to capture both echocardiographic and angiographic 
changes related to vasospasm without the use of any provoking manoeuvres.

\section{Learning points}

- Echocardiographic evidence of transient wall motion abnormalities without provocation further increases the clinical suspicion and pre-test probability of diagnosing coronary vasospasm on angiography.

- In the absence of significant coronary artery disease, ergonovine echocardiography can be safely used for diagnosis of coronary vasospasm.

- Coronary vasospasm is an uncommon presentation of acute coronary syndrome with tobacco abuse being the most significant predisposing risk factor.

Contributors PKP was involved in taking history and doing physical examination on the patient in the ER. YA and AH rounded on the patient on general medical floor and read the patient's echocardiogram when the patient was having chest pain episodes. YA and FA performed cardiac catheterisation on the patient.
Funding The authors have not declared a specific grant for this research from any funding agency in the public, commercial or not-for-profit sectors.

Competing interests None declared.

Patient consent for publication Obtained.

Provenance and peer review Not commissioned; externally peer reviewed.

\section{ORCID iD}

Yashwant Agrawal http://orcid.org/0000-0002-1352-583X

\section{REFERENCES}

1 Kleyman R, Goyal R, Patel N, et al. Vasospastic angina and role of cardiac catheterization. Cureus 2019:11:e5588.

2 Park JH. Ergonovine provocation echocardiography for detection and prognostication in patients with vasospastic angina. Korean Circ J 2018:48:917-9.

3 Picard F, Sayah N, Spagnoli V, et al. Vasospastic angina: a literature review of current evidence. Arch Cardiovasc Dis 2019:112:44-55.

4 Song JK, Lee SJ, Kang DH, et al. Ergonovine echocardiography as a screening test for diagnosis of vasospastic angina before coronary angiography. J Am Coll Cardiol 1996:27:1156-61.

5 Om SY, Yoo S-Y, Cho G-Y, et al. Diagnostic and Prognostic Value of Ergonovine Echocardiography for Noninvasive Diagnosis of Coronary Vasospasm. JACC Cardiovasc Imaging 2020:S1936-878X.

Copyright 2020 BMJ Publishing Group. All rights reserved. For permission to reuse any of this content visit https://www.bmj.com/company/products-services/rights-and-licensing/permissions/

BMJ Case Report Fellows may re-use this article for personal use and teaching without any further permission.

Become a Fellow of BMJ Case Reports today and you can:

- Submit as many cases as you like

Enjoy fast sympathetic peer review and rapid publication of accepted articles

- Access all the published articles

Re-use any of the published material for personal use and teaching without further permission

Customer Service

If you have any further queries about your subscription, please contact our customer services team on +44 (0) 2071111105 or via email at support@bmj.com.

Visit casereports.bmj.com for more articles like this and to become a Fellow 